\title{
The Fight of Telephus: Poetic Visions behind the Pergamon Frieze
}

\author{
Laura Lulli
}

Tracing the possible reciprocal influences between the visual arts and literary works is always an interesting challenge, since it enables one to highlight the huge variety of suggestions, influences, tendencies, and aims that lie behind a work of art. ${ }^{1}$ This process is even more complex when it is applied to the ancient world: in this case it is essential to exercise caution, since the scholarly tradition often has to deal with influences which are neither immediately explicit nor hardly ever documented by 'statements of intent' on the part of the artists. However, even if it may not be possible to pinpoint in a figurative work an explicit allusion to a literary work, nevertheless it is worthwhile to try to compare the two art forms. ${ }^{2}$ In doing so it is important to regard them not as two distinct objects connected merely by the attempt at comparison proposed by the scholar, but rather as two interconnected spheres, sometimes moving in parallel and sometimes intersecting with a lesser or greater degree of selfconsciousness. ${ }^{3}$

With this in mind I have tried to read afresh some scenes of the so-called 'smaller frieze' of the altar at Pergamon, that is the frieze in which the life and exploits of the hero Telephus are represented. ${ }^{4}$ The standard interpretation of

* For suggestions received I would like to thank Luca Bettarini, Ewen Bowie, Michele Napolitano, Bruna Marilena Palumbo Stracca, Massimiliano Papini, and Livio Sbardella. Translations from Greek are my own where not otherwise stated.

1 This topic has been dealt with from many angles in a massive bibliography referring to different historical periods. I here limit myself to mentioning only a few towering works such as those of Gombrich (1966) on the Renaissance, and Ginzburg (1981) on Piero della Francesca.

2 For a broader perspective on the possible relationships between Greek choral song in particular and the iconographical evidence see Athanassaki's chapter in this volume.

3 There is a huge bibliography on the influences between poetry and figurative art in the ancient world; I mention here only Shapiro (1994), Snodgrass (1998), and Vetta (2001), which pay special attention to epic and lyric poetry; cf. also Taplin (2007) on the relationship between tragedy and vase-painting.

4 For an overall analysis of the Telephus frieze on the Pergamene altar see Dreyfus and Schraudolf (1996).

(C) LAURA LULLI, 2016 | DOI: 10.1163/9789004314849_004

This is an open access chapter distributed under the terms of the Creative Commons Attribution-

Noncommercial 3.o Unported (CC-BY-NC 3.0) License. 
the frieze is based on identifying the influence on the myth's representation of two main genres of the Greek literary experience: archaic epic on the one hand, and tragedy on the other. ${ }^{5}$ At any rate, a closer look at some details of the frieze, and in particular at the scenes dealing with the Mysian battle (fig. 3.1), enables a reappraisal of the possible literary influences behind this representation of the Telephus myth on the Pergamon frieze.

The Mysian battle is an episode from the central period of Telephus' life, soon after the adventures of his early years and before his involvement in the events of the Trojan war, when, following the instructions of an oracle, he helped the Achaeans to land at Ilium. Our knowledge of this section of the Telephus myth is due for the most part to the evidence of the cyclic epic poems, Hesiodic poetry, tragedy, and the erudition of Philostratus and Pausanias. ${ }^{6}$ It will be helpful in the first instance to examine this evidence in order to understand its value; I will discuss later the handling of the Telephus myth in lyric and elegiac poetry, since this shows features which are peculiar compared to other literary testimonies of the same myth.

Among our earliest sources for the Mysian battle is the cyclic epic Cypria, which narrates the events leading up to the Trojan war. Althought the date of the poem is controversial, most scholars would agree that the Cypria, like other cyclic epics, originates in the diffusion of rhapsodic activity between the late eighth and the early sixth centuries BC. ${ }^{7}$ Thanks to the summary in Proclus' Chrestomathia, we know that the Cypria also mentioned the Mysian battle, in which Telephus was wounded in a duel with Achilles while repelling the attack of the Achaeans, who had mistaken his land for Troy.

Cypr. Argumentum Procl. Chrest. 80 Severyns (= pp. 38-43 Bernabé $=$ pp. 30-33 Davies)

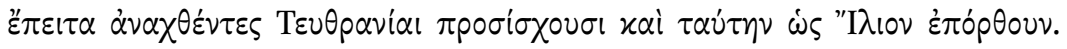

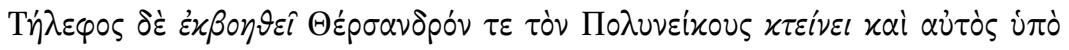

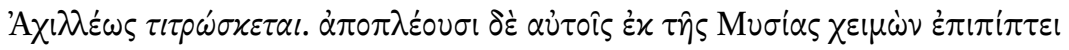

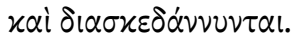

5 The first attempt at a comparison between the literary tradition and the scenes of the Telephus frieze can be read in Robert (1887), especially pp. 254-259 (on the Mysian battle), Robert (1888a), and Robert (1888b), whose work is still the starting point of the majority of the interpretations of the frieze.

6 See, in particular, Paus. 8.4.9, 8.47.4, 8.48.7, 8.54.6.

7 On the chronology of the Cypria see Burgess (1996) 77 n. 2, West (1995) 204, and West (2013) $63-65$. 
Then they put to sea and land at Teuthrania, and they were setting out to sack it thinking it was Ilion. Telephus comes out to defend it, kills Polynices' son Thersander, and is himself wounded by Achilles. As they are sailing away from Mysia, a storm catches them and they become dispersed.

trans. M.L. WEST

From this brief summary only the fundamental details of the episode emerge: the intervention of Telephus in defence of his own city, besieged by the Achaeans, the killing of Thersander, son of Polynices, and, finally, the wounding of Telephus by Achilles. It is difficult to infer from this outline which thematic and verbal formulae were used in the epic poem for the description of this battle scene.

In the Epitome of Apollodorus' Bibliotheca we find a more detailed account of the events, though they still correspond to the scheme found in the summary of the Cypria just mentioned (invasion of Mysia by the Achaeans / resistance and reaction on the part of Telephus / killing of Thersander / wounding of Telephus):

Apollod. Epit. 3.17

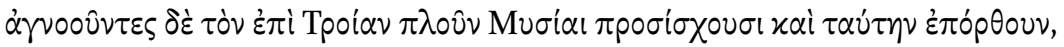

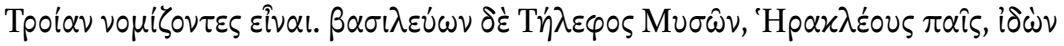

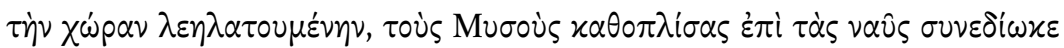

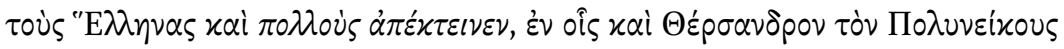

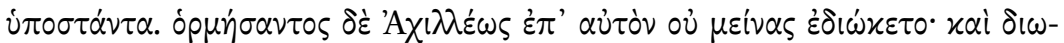

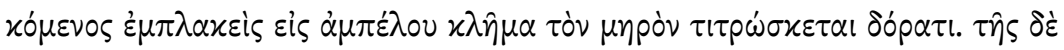

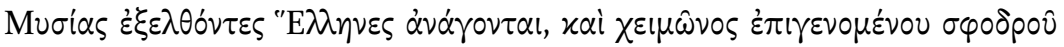

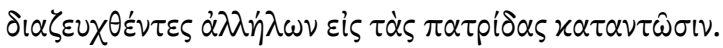

But not knowing the course to steer for Troy, they put in to Mysia and ravaged it, supposing it to be Troy. Now Telephus, son of Hercules, was king of the Mysians, and seeing the country pillaged, he armed the Mysians, chased the Greeks in a crowd to the ships, and killed many, among them Thersander, son of Polynices, who had made a stand. But when Achilles rushed at him, Telephus did not abide the onset and was pursued, and in the pursuit he was entangled in a vine-branch and wounded with a spear in the thigh. Departing from Mysia, the Greeks put to sea, and a violent storm coming on, they were separated from each other and landed in their own countries.

trans. J.G. FRAZER 
When we compare Apollodorus' account with the information given in the summary of the Cypria we find one additional detail: Telephus killed many soldiers ( $\pi \circ \lambda$ ov่ $\dot{\alpha} \pi \varepsilon \dot{\varepsilon} \tau \varepsilon i v \varepsilon v)$. Although at first sight this might seem insignificant and even banal, it should be kept in mind, since it suggests an attempt to describe the extreme brutality of the battle, and not just the main elements of Telephus' clashes with individual heroes, in primis Thersander and Achilles. It cannot be excluded that Apollodorus relied upon Alexandrian scholarship for this account of the Mysian battle. In this connection it is worth examining a scholium to line 59 of the first book of the Iliad:

\section{Cypr. fr. 20 (I) Bernabé = schol. D Il. 1.59 van Thiel}

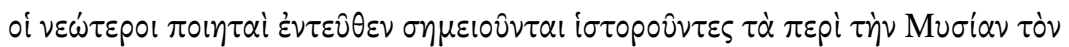

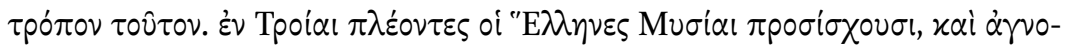

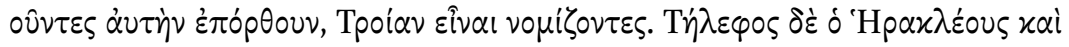

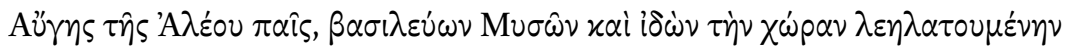

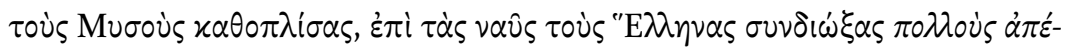

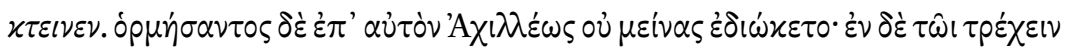

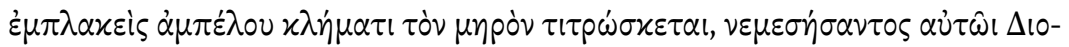

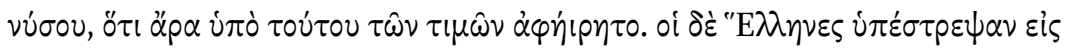

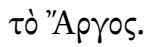

The younger poets are distinguished because they recount the events concerning Mysia in the following way. The Greeks, sailing to Troy, landed in Mysia and, not recognizing it, plundered it thinking that it was Troy. Then Telephus, son of Herakles and Auge, the daughter of Aleos, being king of the Mysians and seeing that his land was plundered, armed the Mysians and chased the Greeks back to their ships killing many. But when Achilles rushed headlong at him he did not stand fast and was pursued: while running, entangled by a vine branch, he is wounded on the leg, for Dionysus was angry with him for depriving him of his honours. Then the Greeks turned back toward Argos.

Here the scholiast, while giving the main outlines of the Mysian battle, stresses that Telephus 'killed many' Greeks. It is clear that Alexandrian scholars, in

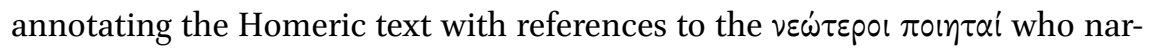
rated the Mysian battle, ${ }^{8}$ considered it important not only to give a report of

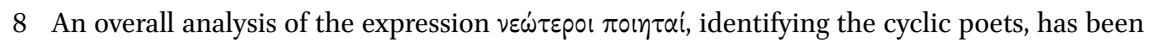
done by Severyns (1928) 31-101. 
the sequence of events, but also to specify the bloodiness of the battle, adding the significant detail of the killing of many Greeks at the hands of Telephus.

Another well known archaic source for the Telephus myth is Hes. fr. 117 Most (= fr. 165 M.-W. = P. Oxy. 11. 1359 fr. 1) of Hesiod's Catalogue of Women. ${ }^{9}$ After a section of the poem concerning the birth of Telephus from Auge and Heracles, at lines 12-25 it is possible to see the traces of a reference to his Mysian adventures:

Hes. fr. 117.12-25 Most

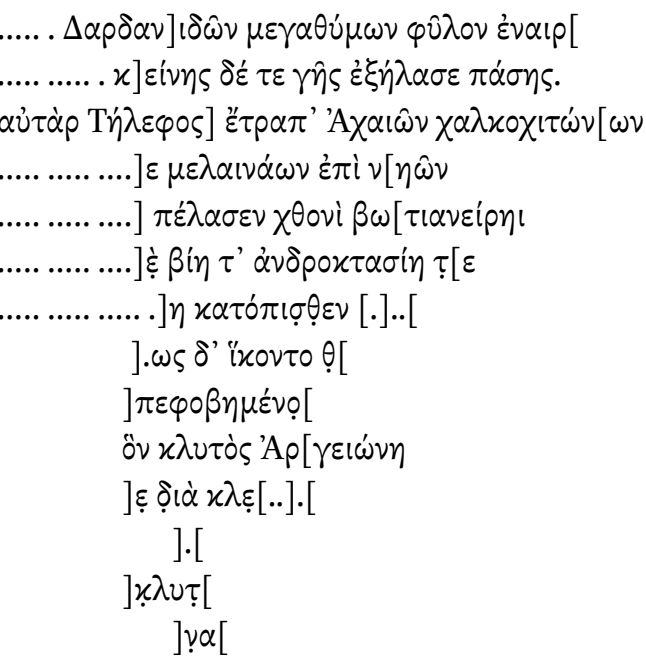

] slew the tribe of great-spirited [Dardanians

] and drove them out from the whole country.

Then Telephus] fled from the Achaeans with their bronze tunics

15

] on black ships

] he brought down to the man-feeding land ] force and slaughter ] in later times [ ] they came [

20 ] frightened [ whom] glorious [Argea bore

trans. G.W. MOST

9 For the collocation of this fragment in the Arcadian stemma of the Catalogue see West (1985) 42-43, 90-91. See also Haubold (2005) 89 n. 22. 
In these very fragmentary lines (especially $14 \mathrm{ff}$.) the narrative of the Mysian battle focuses on Telephus, who tries to defeat the Greeks and turn them away from his kingdom but is wounded by Achilles. However, it does not set out to describe the bloody scene of the battle in vivid terms. This fragment of the Catalogue of Women, then, depicts the Mysian battle in the same terms and following the same narrative scheme as that we have seen in the Cypria.

Similarly to what happens in the hexametric poetry of the archaic periodof which we have seen two examples in the Cypria and the Catalogue of Women - the Telephus myth also receives a detailed treatment in Attic drama of the fifth century вс. ${ }^{10}$ However, the extreme fragmentariness of the plays in which the hero appeared does not allow us to reach a complete understanding of their handling of the myth. This is the case, for example, for the Mysians $^{11}$ and the Telephus ${ }^{12}$ attributed to Aeschylus, of which we know little more than the title and some sporadic quotations from lexicographers, and for Sophocles' Mysians. ${ }^{13}$ Euripides' Telephus, known only through fragments, is thought to be the third play of a tetralogy consisting of The Cretan Women, Alcmaeon in Psophis, and Alcestis. ${ }^{14}$ Based on the sections of the play that we can reconstruct from the surviving papyrus fragments ${ }^{15}$ it is possible to say that the Mysian battle was narrated in the prologue, which can be read in a papyrus from the Milanese collection (P. Mil. I.2 15) $\cdot{ }^{16}$ Moreover, in the extant lines there is no reference to the bloody and violent aspects of the action. ${ }^{17}$ In short, the

10 A useful analysis of the handling of the Telephus myth in fifth-century drama can be found in Platter (2007) 143-175.

11 See Aesch. frr. 143-145 Radt. The most important source for this drama is Arist. Poet. 1460a.27, where Telephus is defined $\delta \ddot{\alpha} \varphi \omega \nu$ os. For this appellative of Telephus see Alex. fr. 183.3-4. Kassel-Austin, Amphis fr. 30.5-14 Kassel-Austin. To the Mysians have been attributed dubiously also frr. * $239,354,379$ Radt.

12 See Aesch. frr. 238-240 Radt.

13 See Soph. frr. 409-418 Radt. According to a fourth-century inscription $\left(\mathrm{IG} \mathrm{II}^{2} 3091.8=\operatorname{Tr} G F\right.$ I 39), this drama was part of a Telepheia, which would have included also a Telephos (fr. 580 Radt). On the inscription see Pickard-Cambridge (1933) and Ghiron-Bistagne (1976) 9597. On the controversial nature of the Sophoclean Telephus, regarded by some critics as a satyr play, see TrGF IV 434 and Sutton (1974).

14 This information is known from one of the two hypotheseis of the Alcestis: see Del Freo (1996) 198, 204-209, with an analysis of the evidence for Euripides' Telephus.

15 P. Mil. I.2 15 = Eur. fr. 696 Kannicht; P. Oxy. XxviI 2460 = fr. 727 a Kannicht; P. Ryl. III $482=$ fr. ${ }^{* *} 727$ b Kannicht; BKT 5.2 pp. 64-72 n. XVI = fr. 727c Kannicht.

16 The standard reconstruction of the sections of the drama is in Handley and Rea (1957), with a discussion of the fragments. For an analysis of the whole tetralogy see Del Freo (1996).

17 It should be added that, as suggested by Handley and Rea (1957) 28-29, Accius' lost 
fragmentary state of the plays of the three Attic tragedians dealing with the Telephus myth does not allow us to reach any firm conclusions; however, on the basis of what survives, it does not seem that in those tragedies the violent aspects of the Mysian battle received special emphasis.

There is evidence for the literary use of the myth of Telephus also in the Hellenistic period. In particular, P. Oxy. II 214, published in 1899 by Bernard P. Grenfell and Arthur S. Hunt, ${ }^{18}$ is of great interest. It contains an anonymous poetic fragment, with parts of forty-three hexameter lines written on the remains of a leaf from a third-century papyrus codex. ${ }^{19}$ On the verso, it is possible to read a very lacunose group of verses devoted to a description of the dangers of travelling by sea. On the recto there is a speech, probably spoken by a woman, ${ }^{20}$ about Telephus' adventures and, in particular, the very first part of his story in Mysia: lines 2-5 deal with the defeat of the Greeks at the hands of our hero. ${ }^{21}$ Another indication of the probable use of the Telephus myth in the Hellenistic age has been found in a scholium to Apollonius Rhodius, where it seems to be said that Philitas of Cos was the author of a poem entitled Telephus. ${ }^{22}$

At any rate, in order to find some clear traces of a vivid representation of the bloodiness of the Mysian battle, we must turn our gaze to archaic lyric and elegiac poetry. Here the most interesting item is the well known P. Oxy. LXIX 4708, published by Dirk Obbink in $2005,{ }^{23}$ thanks to which it has

drama about Telephus may have been modelled on Euripides'. For a useful analysis of the influence of Telephus' myth on Latin literature see Fantham (2009).

18 A further edition of the text is in Heitsch (1963) $5^{8} \mathrm{n}$. XVIII. A literary study of the fragment is in Pellin (2010).

19 To be more precise, the editors state that this papyrus fragment is 'presumably a leaf out of a book' (P. Oxy. II, p. 27).

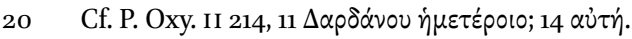

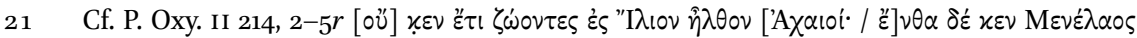

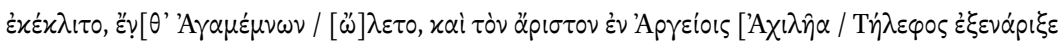

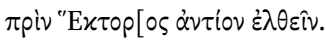

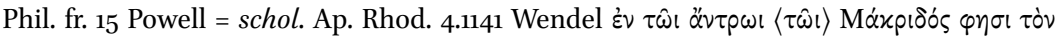

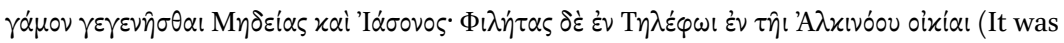
in the cave of Macris that he [scil. Apollonius] says that the wedding of Jason and Medea took place, whereas Philitas in the Telephus said it was in the palace of Alcinous. [trans. J.L. Lightfoot]). It should be noted that the text of the scholium is far from unproblematic and there are some, such as Bach (1829) 6o, who try to correct it in order to read $\delta$ T $\eta \lambda \dot{\varepsilon} \varphi \circ v$, i.e. a reference to Philitas' father instead of a title. On the Telephus attributed to Philitas of Cos see Sbardella (2000) 41-44, with a reconstruction of the debate and further bibliography, and Spanoudakis (2002) 92, 309-311. 
been possible to recover a long elegy by Archilochus concerning the myth of Telephus. It is worthwhile to look especially at the following verses:

P. Oxy. LXIX 4708 fr. $1.5^{-15}$

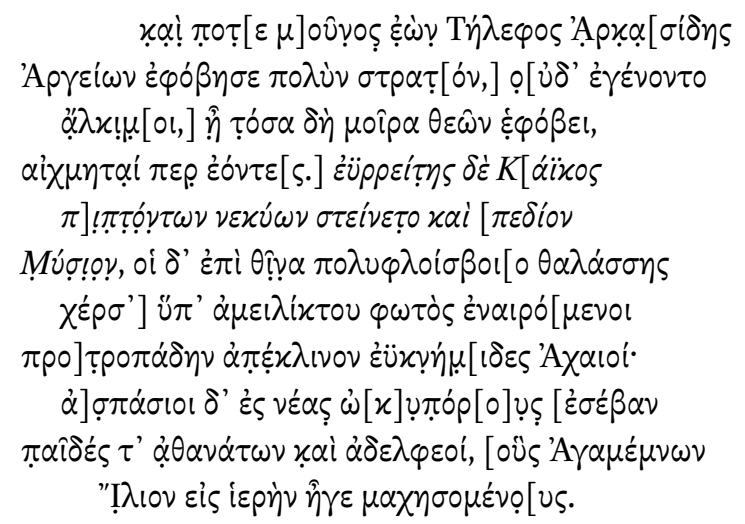

Even once Telephus, descendant of Arkasos, by himself put to flight the great army of Argives, and they were not brave-indeed, so greatly was the fate of the gods routing them-powerful spear-men though they were. The fair-flowing river Kaikos and the plain of Mysia were stuffed with the falling corpses, while the well-greaved Acheans, being slain at the hands of the relentless man (Telephus), turned-off with headlong speed to the shore of much-resounding sea. Gladly did they embark on their swift ships, the sons of the immortals and brothers, whom Agamemnon was leading to holy Ilios to wage war.

trans. D. овВINK, with modifications

In these lines, which seem to have followed immediately after the now lost opening section of the elegy, much space is given to the narration of the myth of Telephus and, more specifically, to the landing of the Achaeans in Mysia and their consequent fight with the local population led by their king Telephus. What is striking in these elegiac distichs is the description of the violence of the war action, which involves both the river Kaikos and the Mysian plain being filled with the corpses of the fallen (ll. 8-10): to depict this, the poet uses the

and D'Alessio (2006). For a useful synthesis of the debate about the new Archilochus elegy on Telephus see Nicolosi (2005) 80-87, Nicolosi (2006), Nicolosi (2007) 279-333, and Lulli (2011) 87-105. 
expression $\nu \varepsilon \varkappa u ́ \omega \nu ~ \sigma \tau \varepsilon i v \varepsilon \tau 0$, which has its roots already in $\mathrm{Homer}^{24}$ and can be found in the same form much later in Quintus Smyrnaeus. ${ }^{25}$

A similar grim image can be seen in Pindar's eighth Isthmian ode, where the poet makes an explicit, if brief, reference to the Telephus myth.

Pind. Isthm. 8.49-50

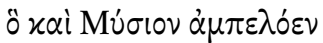

50

$\alpha i \mu \alpha \xi \varepsilon \mathrm{T} \eta \lambda \varepsilon \dot{\varepsilon} \varphi 0 \nu \mu \varepsilon \dot{\varepsilon} \lambda \alpha \nu$

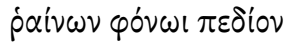

He also bloodied the vine-clad

5o plain of Mysia

with the dark drops of Telephos' gore

trans. W.H. RACE

In this section of the ode the poet lists all of Achilles' military achievements, including the wounding of Telephus during the fight between the Achaeans and the Mysians. In this case, too, the bloodiness of the fight between the two demigods is a striking feature: ${ }^{26}$ Achilles is said to stain with blood the Mysian plain, soaking it with the dark blood of Telephus. ${ }^{27}$

After Pindar we must wait until the age of the Second Sophistic to find another literary representation of the vivid bloodiness of the Mysian battle. The section of Philostratus' Heroicus ${ }^{28}$ devoted to the life and exploits of Telephus includes a description of the Mysian battle:

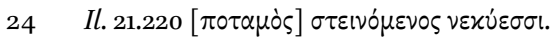

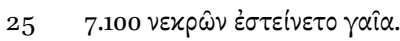

26 The particularly grim tone of this battle scene description is noted also by Privitera (1982) ad loc.: 'Pindaro amplifica e carica le tinte'.

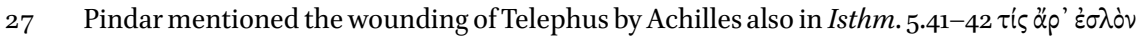

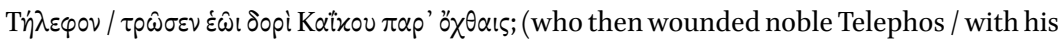

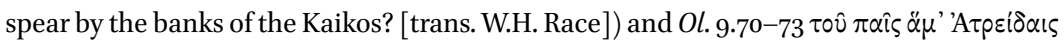

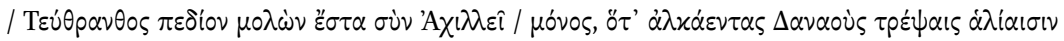

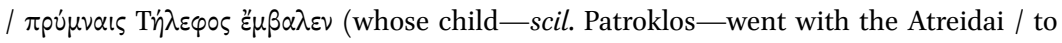
the plain of Teuthras and stood by Achilles / all alone, when Telephos routed the valiant Danaans / and attacked their seaworthy sterns [trans. W.H. Race]).

28 On Philostratus' Heroicus see Kim (2010) $175^{-215}$, with further bibliography; Bowie and Elsner (eds) (2009) provides a general and comprehensive introduction to the author and his work. 
Philostr. Her. 23.24-25 De Lannoy

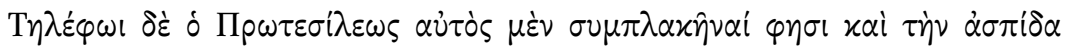

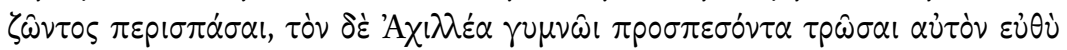

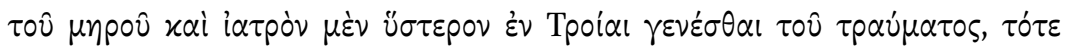

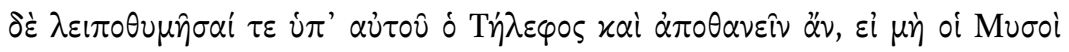

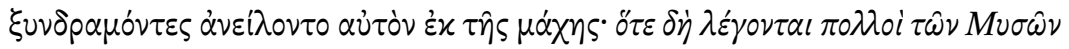

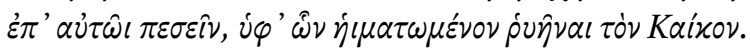

Protesilaos says that he himself fought Telephos and stripped him of his shield while still alive, but that Achilles fell upon the unprotected man, wounding him at once in the thigh. And although later in Troy he healed the wound, at that time Telephos lost heart because of it and would have died if the Mysians had not together run to Telephos and snatched him out of the battle. So many Mysians are said then to have fallen for him that the Kaikos river ran red with their blood.

trans. J.K. BERENSON MACLEAN - E. BRADSHAW AITKEN

The casualties among the ranks of the two fighting armies were such that the river Kaikos literally ran red with the blood of the soldiers. This detail is not a decorative addition to the tale ascribable to Philostratus' sensibility or perspective. Rather, as we have previously noted, this violent element providing a strong visual impact can be seen in the very first literary testimonies of the Mysian battle, i.e. in elegiac and lyric poetry, much more than in epic and tragedy. Philostratus' tale distinguishes itself by a striking visual proximity to Pindar's description of the same episode: in both cases the flow of blood stains red the banks of the river Kaikos, obstructed by the bodies of the fallen, and the

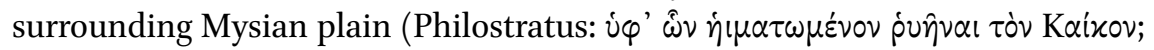

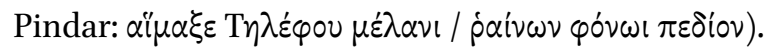

This representation of the bloodiness of the battle finds a close parallel in the iconography of the Mysian struggle on the Telephus frieze inside the inner porch of the so-called Great Altar of Pergamon. ${ }^{29}$ The representation of the myth, from Telephus' birth to his last exploits, runs from left to right, following an order which may be thought of as imitating the layout of a text

29 It is important to note that representations of violent battle-scenes can already be found in archaic Greek art, as demonstrated by Schefold (1992), esp. 231-244. On this topic see also Shanks (1999) 107-130. 
written on a papyrus roll. ${ }^{30}$ As is well known, the absolute novelty of this frieze lies in its use of a narrative structure which requires the spatial placement of human figures and objects according to their relative importance in the economy of the story. ${ }^{31}$ Far from conforming to the usual naturalistic criteria typical of Greek art, the images are arranged regardless of their real proportions: the organization of the figures is thus subject only to the needs of the story and the desire to show the viewers the main details of the myth. ${ }^{32}$ In spite of the fragmentary state of some pieces-as is well known, the fragmentary and unfinished state of the frieze has always been one of the main problems for the overall interpretation of the work, as well as for the understanding of its individual parts ${ }^{33}$ - the iconography of the scenes represented in some frames of the Telephus frieze ${ }^{34}$ resembles quite closely the narrative technique found in the literary evidence already examined. The narrative sequence begins with the death of Hiera, the Amazon wife of Telephus (fig. 3.1-3.2), who fell in battle after leading the Mysian women against the Achaean invaders. The frames which follow show some crucial moments of the battle, for example the death of two warriors (fig. 3.3-3.4), generally identified as Aktaios, son of the river-god Istros and a Trojan ally, and his brother Heloros, both killed by Ajax son of Telamon, as narrated by Philostratus (Her. 2.15). It is worthwhile examining the depiction of their death: the bodies of the two warriors lying upside down are interlaced and surrounded by the weapons which are no longer in their hands, clearly indicating their defeat. This seems to recall the image of the casualties in the Mysian battle described in vivid and bloody detail by both Archilochus and Pindar. After this scene we find the pieces showing the wounding of Telephus by Achilles

30 On illustrations on papyrus roll see Horak (1992) and the general remarks in Settis (2006), esp. 50-6o.

31 For an analysis of the narrative technique of the Telephus frieze see Stewart (1996). A reflection on the manner of representation of both space and landscape in the Telephus frieze can be found in Bianchi Bandinelli (1943) 98-101, 138, 222.

A clear description of the main characteristics of the style used in the Telephus frieze is given by Papini (2007) 384-392, who, in comparing the Gigantomachy with the Telephus frieze, states that in the latter 'balza all'occhio la ricerca di profondità spaziale, non senza inflessioni pittoriche, nonché la predilezione per una cornice paesaggistica; ... sul Piccolo Fregio si afflosciano le pieghe, che si fanno meno plastiche e più lineari, talora calligrafiche, si stemperano le forme e si ammorbidiscono le carni; ...' (p. 384).

On the difficulties in reconstructing the structure of the Telephus frieze see Heilmeyer (1996) 37, and Massa-Pairault (1998) 93.

34 See plates 22-33 LIMC s.v. Telephos VII.1, p. 860. 


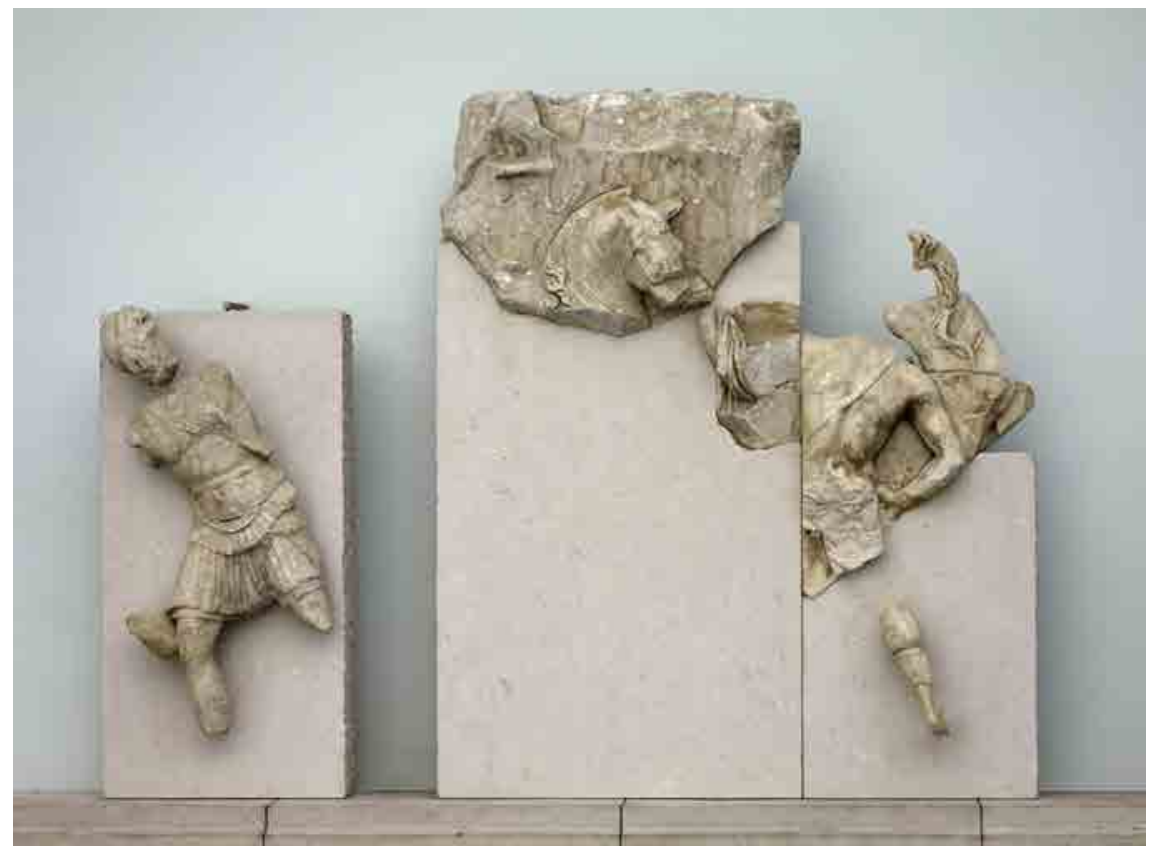

FIG. 3.1 Hiera, Telephus' wife, against the Greek warriors, from the Pergamon Great Altar (C) STAATLICHE MUSEEN ZU BERLIN, ANTIKENSAMMLUNG, PHOTOGRAPHER: JOHANNES LAURENTIUS

(fig. 3.5), helped by the epiphany of Dionysus. Lastly, the cycle of the Mysian battle is concluded by the stelai depicting the flight of the Achaeans to their ships.

The Telephus frieze, commissioned by the Attalids with the chief purpose of emphasizing the origin of their dynasty from Heracles, ${ }^{35}$ can be viewed as integral to their political and cultural strategy, which aimed to make Pergamon an undisputed capital of the Hellenistic world, a new Athens. ${ }^{36}$ In this context, as is well known, the recovery of the literary tradition of the archaic and classical periods played and important role; Pergamene scholars devoted huge efforts to this enterprise, in constant competition with other centres of erudite studies, above all Alexandria. The literary influences which the artists of the Telephus frieze must have had in mind without doubt included the earlier epic and tragic traditions, but it is not surprising that archaic lyric and narrative elegy played

\footnotetext{
$35 \quad$ See Moreno (1977) 451.

36 For an overall analysis of the main aspects of the Attalids' political and cultural perspectives see Virgilio (1993).
} 


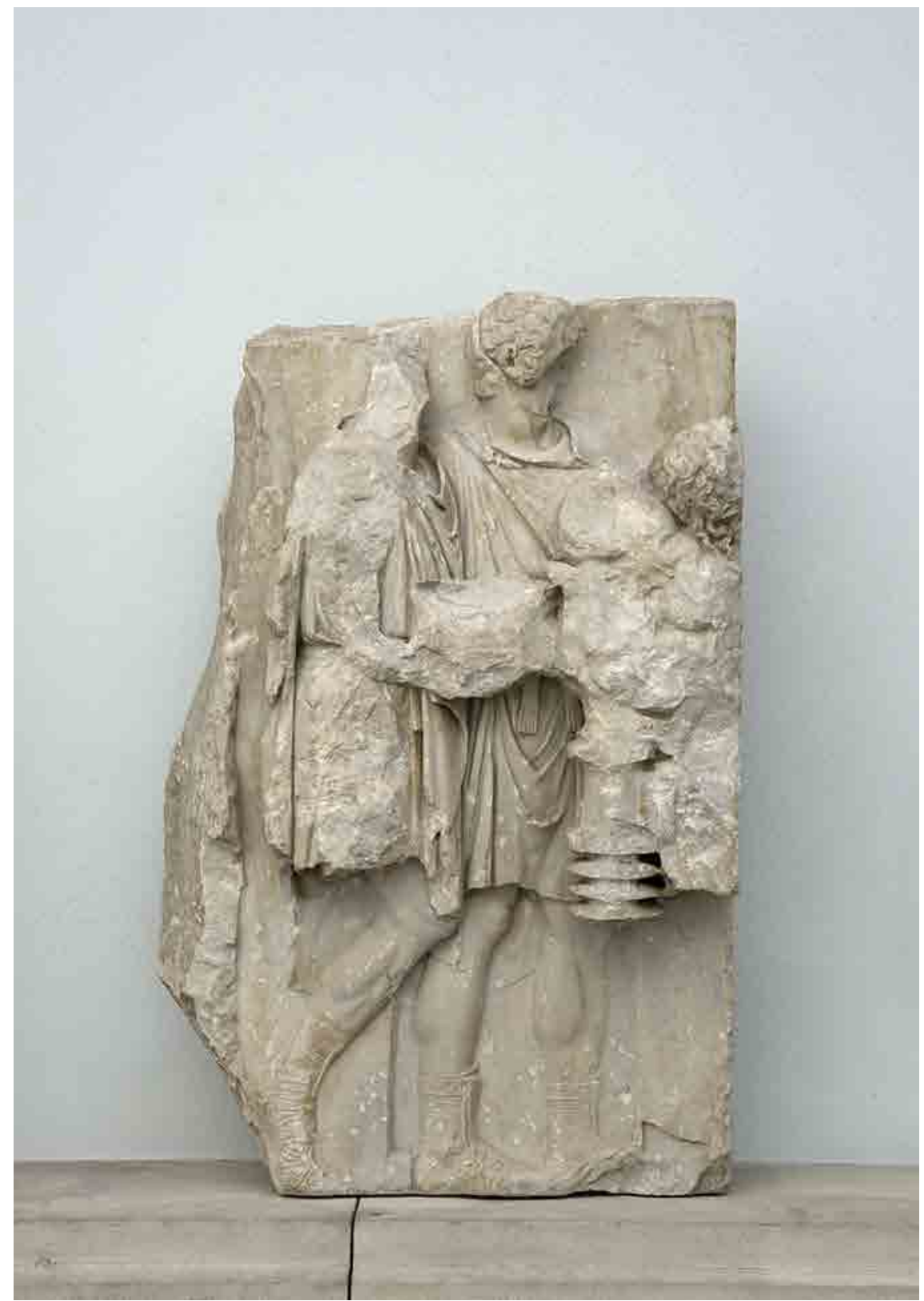

FIG. 3.2 Hiera's funeral, from the Pergamon Great Altar

(C) STAATLICHE MUSEEN ZU BERLIN, ANTIKENSAMMLUNG, PHOTOGRAPHER: JOHANNES LAURENTIUS 


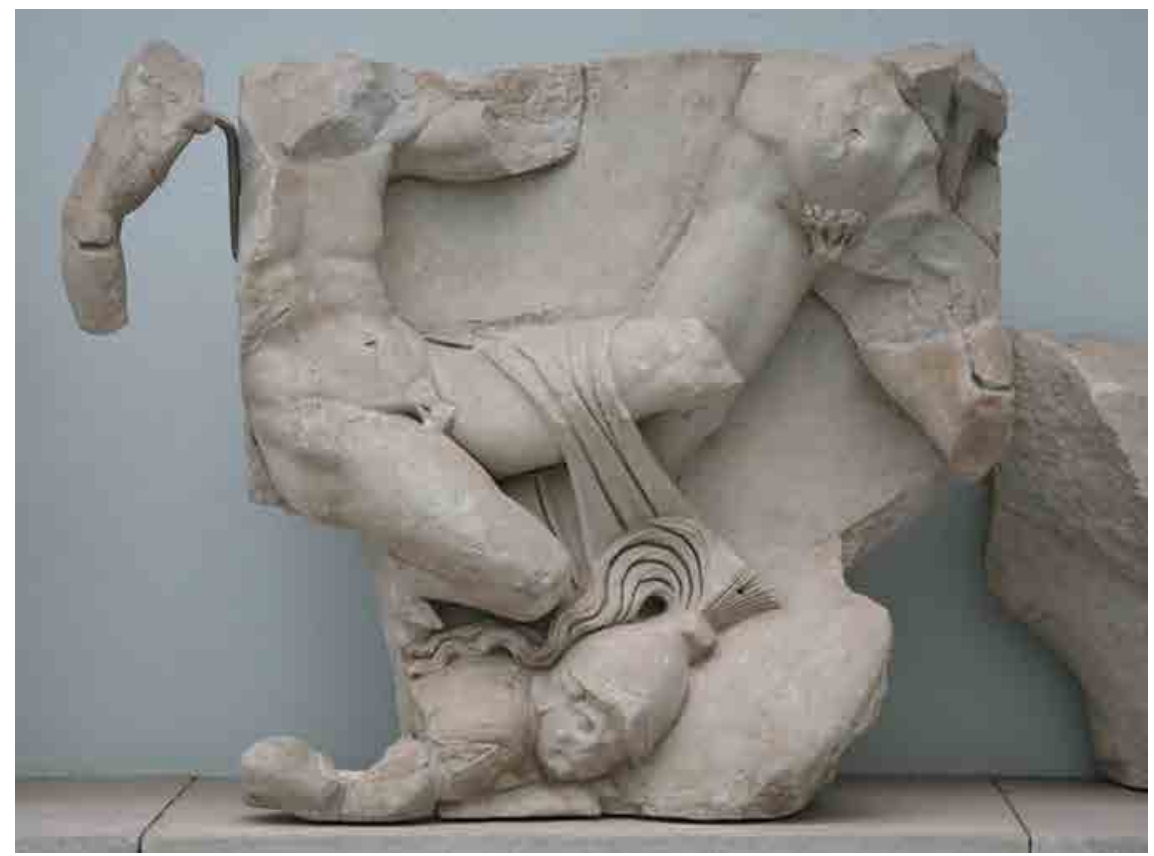

FIG. 3.3

The death of two warriors, from the Pergamon Great Altar

(C) STAATLICHE MUSEEN ZU BERLIN, ANTIKENSAMMLUNG, PHOTOGRAPHER: JOHANNES LAURENTIUS

a part in the formation of the iconography of the Telephus myth chosen in Pergamon. ${ }^{37}$ Indeed, thanks to the learned remarks of the Hellenistic scholars and the intellectuals of the Second Sophistic the image of the tragic and bloody Mysian battle passed beyond the chronological limits of Archilochus and Pindar, who were the first to display all its figurative potentialities. We can-

37 In this regard the following information offered by Pausanias (3.26.9-10) is also interesting:

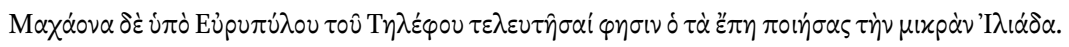

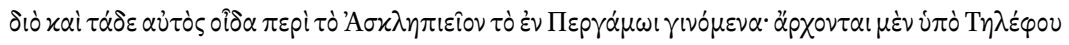

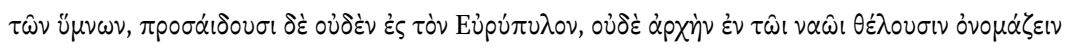

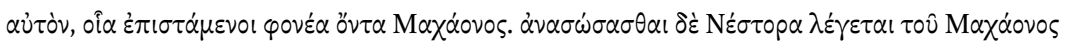

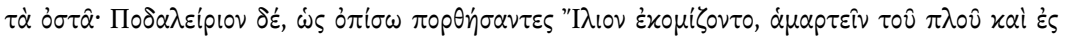

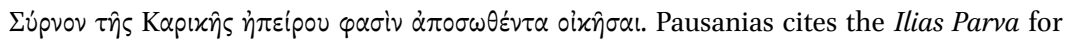
the report that Machaon was killed by Eurypylus, son of Telephus. This is followed by a reference to the rites at the temple of Asclepius and to the hymns in honour of Telephus. So in Pausanias' day not only was the distant memory of the hero's adventures still alive, but his value for the political and religious life of the city of Pergamon also lived on, so that the performace of hymns in his honour continued. 


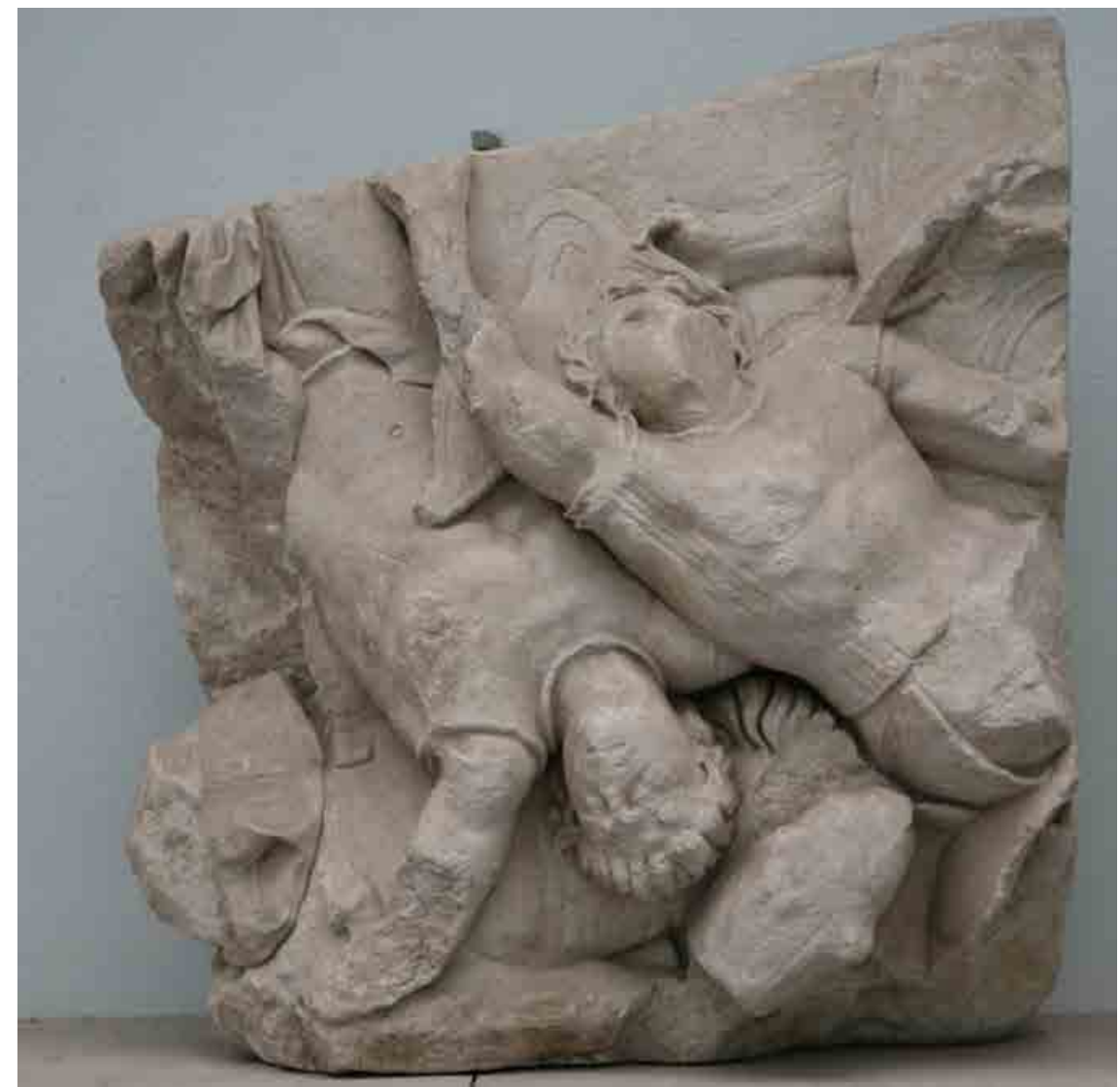

FIG. 3.4

The death of Aktaios, from the Pergamon Great Altar

(C) STAATLICHE MUSEEN ZU BERLIN, ANTIKENSAMMLUNG, PHOTOGRAPHER: JOHANNES LAURENTIUS

not exclude that the artists of the parts of the frieze showing the Mysian battle looked to those poetic compositions: on the one hand the Archilochean narrative elegy and on the other the Pindaric celebratory ode, both distinguished by a strong adherence to their contemporary historical and political reality.

In a period when Hellenistic rulers like the Attalids were devising political and cultural programmes, not only in order to emphasize their own superiority over the barbaric populations they confronted, but above all to re-establish a strong link with past tradition and present themselves as Greeks with a welldocumented identity, the use of the Telephus myth had a well-established strategic value: in Greek mythology Telephus, as an Arcadian hero and son of Heracles, always had to relate to 'other' populations, from the Trojans in the East to the Etruscans in the West, while always maintaining his own Greek- 


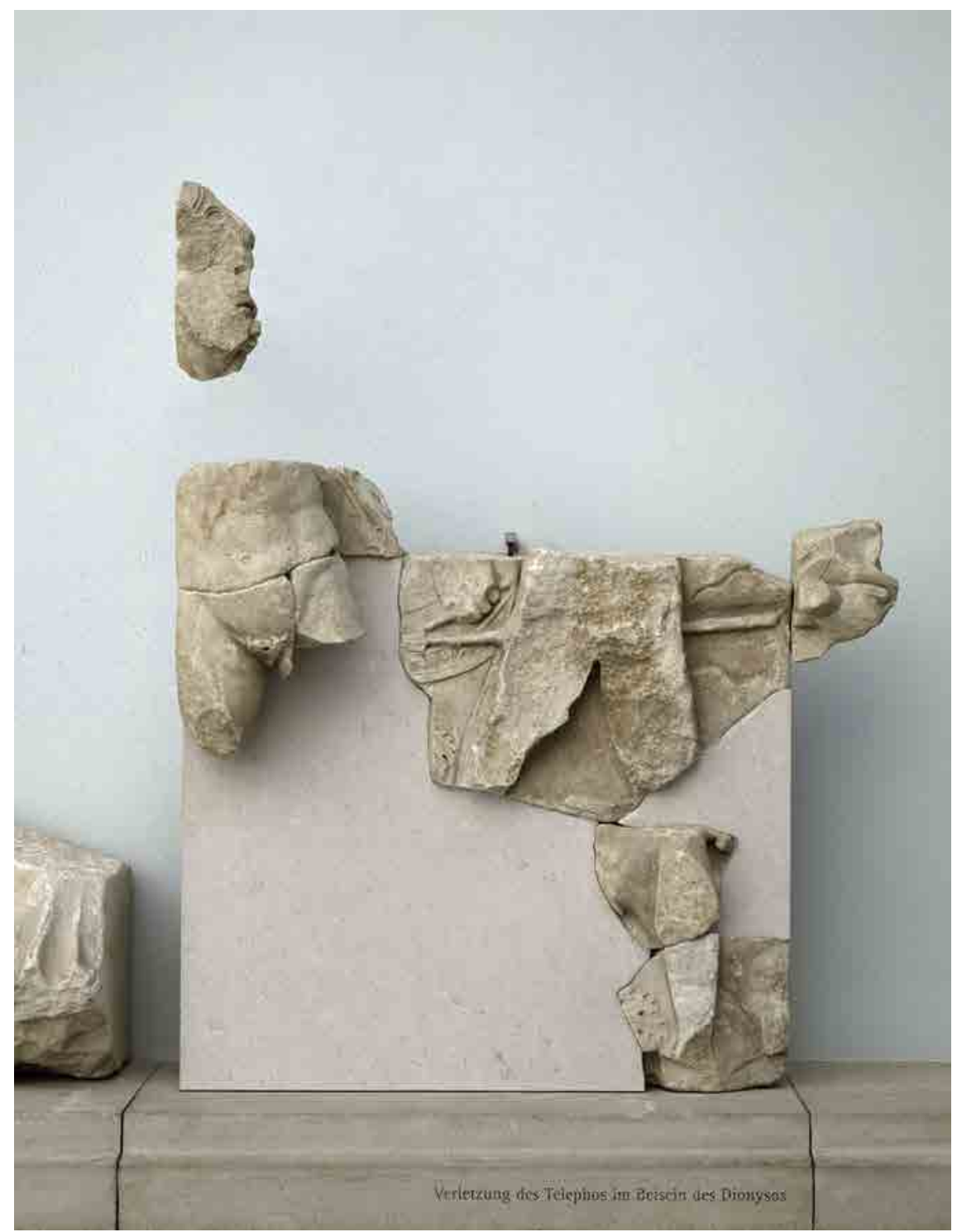

FIG. 3.5

The wounding of Telephus by Achilles, from the Pergamon Great Altar

(C) STAATLICHE MUSEEN ZU BERLIN, ANTIKENSAMMLUNG, PHOTOGRAPHER: JOHANNES LAURENTIUS

ness. In selecting the main features of Telephus' life in order to depict them on one of the most emblematic monuments in Pergamon, it was inevitable that the artists should draw on a manifold and complex iconographic heritage. Moreover, in the specific case of the Mysian battle the artists could have 
relied upon paradigms not limited only to epic and tragedy but also open to the influences of archaic elegy and lyric. The papyrological discoveries testify to the interest in such compositions on the part of the Greek population of Ptolemaic and Roman Egypt, and from this point of view one of the most important examples is the papyrus of Archilochus' Telephus elegy discussed above. It cannot be excluded, therefore, that in another corner of the Greek Hellenistic world the Pergamene scholars, who were in constant competition with Alexandria, devoted their erudition to the recovery of similar lyric and elegiac poems. Indeed, the library of Pergamon, which had been planned by the Attalids with storage rooms for the books and a main room for learned discussions and convivial meetings, and which was adorned with statues of authors of the past such as Herodotus, Alcaeus, and Timotheus, ${ }^{38}$ can be considered a privileged place not only for the conservation of the literary heritage of the past but also for the elaboration of a taste and an iconographic tendency which took into account all the previous, diverse literary influences. Among these a significant role could have been played by Archilochus' narrative elegy and Pindar's poems, in which the myth of Telephus was handled with special attention to the contemporary political and historical reality.

\section{Works Cited}

Canfora, L. (1997 $)$. 'Le biblioteche ellenistiche', in G. Cavallo (ed.), Le biblioteche nel mondo antico e medievale. Rome: $5^{-28}$.

Cavallo, G. (1998). 'Ambizioni universali e isolamento di una cultura', in S. Settis (ed.), I Greci. Storia Cultura Arte Società, 2. Una storia greca. III Trasformazioni. Turin: 215247 .

Bach, J.N.(1829). Philetae Coi, Hermesianactis Colophoniiatque Phanoclis reliquiae. Halis Sax.

Bianchi Bandinelli, R. (1943). Storicità dell'arte classica. Florence.

Bowie, E. and Elsner, J. (eds) (2009). Philostratus. Cambridge.

Burgess, J.S. (1996). 'The non-Homeric Cypria'. TAPhA 126: 77-99.

D’Alessio, G.B. (2006). 'Note al nuovo Archiloco (P.Oxy. LXIX 4708)'. ZPE 156, pp. 19-22.

Del Freo, M. (1996). 'L' Alcesti di Euripide e il problema della tetralogia'.

pp. 197-213.

38 On the library of Pergamon see Cavallo (1998) 233-234, Hoepfner (1996) 40-46, and Canfora $\left(1997^{4}\right)$, 13. For a collection of the evidence on the library of Pergamon see Platthy (1968) 159-165. 
Dreyfus, R. and Schraudolf, E. (eds) (1996). Pergamon: the Telephos Frieze from the Great Altar, I. Austin-San Francisco.

Fantham, E. (2009). 'Telephos at Rome', in J.R.C. Cousland and J.R. Hume (eds), The Play of Texts and Fragments. Essays in Honour of Martin Cropp. Leiden: 421-432.

Ghiron-Bistagne, P. (1976), Recherches sur les acteurs dans la Grèce antique. Paris.

Ginzburg, C. $\left(1981^{3}\right)$. Indagini su Piero. Il Battesimo, il ciclo di Arezzo, la Flagellazione di Urbino. Turin.

Gombrich, E.H. (1966). Norm and Form. Studies in the Art of the Renaissance London. Handley, E.W. and Rea J. (1957). The Telephus of Euripides. BICs Suppl. 5. London.

Haubold, J. (2005). 'Heracles in the Hesiodic Catalogue of Women', in R. Hunter (ed.), The Hesiodic Catalogue of Women. Constructions and Reconstructions. Cambridge: $85^{-98 .}$

Heilmeyer, W.-D. (1996). 'History of the display of the Telephos frieze in the twentieth century', in Dreyfus and Schraudolf (eds) (2006): 29-38.

Heitsch, E. (1963). Die griechischen Dichterfragmente der römischen Kaiserzeit, I. Göttingen.

Hoepfner, W. (1996). 'The architecture of Pergamon', in Dreyfus and Schraudolf (eds) (2006): 23-58.

Horak, U. (1992), Illuminierte Papyri, Pergamente und Papiere, I. Wien.

Kim, L. (2010). Homer between History and Fiction in Imperial Greek Literature. Cambridge.

Lulli, L. (2011). Narrare in distici. L'elegia greca arcaica e classica di argomento storicomitico. Rome.

Massa-Pairault, F.H. (1998). 'Examen de la frise de Télèphe'. Ostraka 7 (1-2): 93-157.

Moreno, P. (1977). 'Da Lisippo alla scuola di Rodi', in R. Bianchi Bandinelli (ed.), Storia e civiltà dei Greci. La cultura ellenistica. Le artifigurative. Milan: 412-460.

Nicolosi, A. (2005). 'Recuperi di lirica greca arcaica da papiri'. A\&R 50: 80-94.

(2006). 'Sul nuovo Archiloco elegiaco (P. Oxy. 4708 fr. 1)'. Eikasmos 17: 25-31.

(2007). Ipponatte, Epodi di Strasburgo. Archiloco, Epodi di Colonia (Con un'appendice su P. Oxy. LXIX 4708). Bologna.

Obbink, D. (2006). 'A new Archilochus poem'. ZPE 156: 1-9.

Papini, M. (2007). 'Dedica, datazione e stili del grande altare di Pergamo'. ArchClass 8: 371-395.

Pellin, A. (2010). 'Il mito di Telefo nell'epos ellenistico:l' 'Epyllium Telephi”, fr. ep. adesp. 3 Powell', in E. Cingano (ed.), Tra panellenismo e tradizioni locali. Generi poetici e storiografia. Alessandria: 519-540.

Pickard-Cambridge, A.W. (1933). 'The inscription from Aexone and the story of Telephus in Sophocles' plays', in J.U. Powell and E.A. Barber (eds), New Chapters in the History of Greek Literature, III. Oxford: 69-84.

Platter, C. (2007). Aristophanes and the Carnival of Genres. Baltimore. 
Platthy, J. (1968). Sources on the Earliest Greek Libraries with the Testimonia. Amsterdam. Privitera, G.A. (1982). Pindaro. Le Istmiche. Milan.

Robert, C. (1887). 'Beiträge zur Erklärung des pergamenisches Telephosfrieses (I-II)'. JDAI 2: 244-259.

- (1888a). 'Beiträge zur Erklärung des pergamenisches Telephosfrieses (III-IVv)'. JDAI 3: 45-65.

- (1888b). 'Beiträge zur Erklärung des pergamenisches Telephosfrieses (VI-VII)'. JDAI 3: 87-105.

Sbardella, L. (2000). Filita. Testimonianze e frammenti poetici. Introduzione, edizione e commento. Rome.

Schefold, K. (1992). Gods and Heroes in Late Archaic Greek Art. Cambridge.

Settis, S. (2006). 'Il Papiro di Artemidoro: un libro di bottega e la storia dell'arte antica', in C. Gallazzi and S. Settis (eds), Le tre vite del Papiro di Artemidoro. Voci e sguardi dall'Egitto greco-romano. Catalogo della mostra, Torino, Palazzo Bricherasio, 8 febbraio - 7 maggio 2006. Milan: 20-65.

Severyns, A. (1928). Le cycle épique dans l'école d'Aristarque. Liège-Paris.

Shanks, M. (1999). Art and the Greek City State. An Interpretive Archaeology. Cambridge. Shapiro, H.A. (1994). Myth into Art. Poet and Painter in Classical Greece. London.

Snodgrass, A. (1998). Homer and the Artists. Text and Picture in Early Greek Art. Cambridge.

Spanoudakis, K. (2002). Philitas of Cos, Leiden.

Stewart, A. (1996). 'A hero's quest. Narrative and the Telephos frieze', in Dreyfus and Schraudolf (eds) (2006): 39-52.

Sutton, D.F. (1974). 'A handlist of satyr plays'. HSCPh 78: 107-143.

Taplin, O. (2007). Pots \& Plays. Interactions between Tragedy and Greek Vase-Painting of the Fourth Century B.c. Los Angeles.

Vetta, M. (2001). 'Immagini e poesia', in M. Vetta (ed.), La civiltà dei Greci. Forme, luoghi e contesti. Rome: $185^{-223}$.

Virgilio, B. (1993). Gli Attalidi di Pergamo. Fama, eredità, memoria. Pisa.

West, M.L. (1985). The Hesiodic Catalogue of Women. Its Nature, Structure, and Origins. Oxford.

- (1995). 'The date of the Iliad'. $M H$ 52: 203-219.

- (2006). 'Archilochus and Telephos'. ZPE 156: 11-17.

(2013). The Epic Cycle. A Commentary on the Lost Troy Epics. Oxford. 